Karolina Bicz*

\title{
ANALYSIS OF THE STRUCTURE AND PRACTICAL ACTIVITY OF THE EUROPEAN FOUNDATION FOR THE IMPROVEMENT OF LIVING AND WORKING CONDITIONS
}

\begin{abstract}
The article presents the structure and practical activity of the European Foundation for the Improvement of Living and Working Conditions. The text consists of the following chapters: introduction, institutional structure, activities and objectives of the European Foundation for the Improvement of Living and Working Conditions, the practical activities of the Foundation, social dimension of intra-EU mobility, its impact on public services and a summary. The author also described the issue of "welfare magnet hypothesis". In general, the article reveals and describes the significance of the institution in the context of the labour law policy operating in the European Union.
\end{abstract}

Keywords: labour law, living and working conditions, European Union law

* Master's Degree in Law, doctoral student at the Faculty of Law, University of Silesia, Katowice 


\section{Introduction}

Numerous international institutions aim at conducting research concerning different fields, for instance: the development of work places, development of business relations, energy policy, operate within the framework of the European Union. The Foundation for the Improvement of Living and Working Conditions is an institution of this type. According to the author, Eurofound is an interesting institution which deserves to be analysed. This institution has a significant impact on European labour law and social rights.

The objective of this article is to discuss the structure, activities, case and significance of Eurofound from the perspective of the European labour law. The first part of the article concerns the legal framework and the scope of the activities of the European Foundation for the Improvement of Living and Working Conditions. The second part is related to practical activity and presents a real case. The author has researched many international materials, such as the directives and EU reports. The main concept of the text is to establish whether the European Foundation for the Improvement of Living and Working Conditions serves a significant role as regards the EU labour law.

\section{Structure of the analysed institution}

The following section is to present the structure and competences of the European Foundation for the Improvement of Living and Working Conditions. Proper organisation of Eurofound is essential to ensure that all tasks assigned to this institution are performed smoothly and without delay. The institution consists of several bodies with clearly defined powers and obligations.

The Foundation is a non-profit organisation operating within the EU, formed on the 26.05.1975. In all Member States of the European Union, the aforementioned Eurofound has a legal personality. The main office is located in Dublin, Ireland.

At the beginning, it is essential to present the ideas, activities and competences of Eurofound. The European Foundation for the Improvement of Living and Working Conditions provides research-based findings and knowledge to support employment and social policies. The ultimate purposes is to help plan and create better living and working conditions in European countries. The basic activities of the organisation include: 
- conducting research on social and work-related issues,

- sharing the results with EU \& national policymakers,

- carrying out research projects and three pan-European surveys on: quality of life, working conditions and company practices,

- it maintains two observatories to keep up-to-date information about: employment changes and working life.

The European Foundation for the Improvement of Living and Working Conditions disseminates its research results and policy-relevant knowledge by: print and online publications, conferences, social media and its website. Eurofound realises projects comprising the annual work programme using the research and monitoring resources mentioned above. Eurofound works closely together on joint analysis and communication activities with its others agencies. ${ }^{1}$ The main objectives of the European Foundation for the Improvement of Living and Working Conditions are to improve working and living conditions in Europe. The role of Eurofound is to inform, consult and prepare expert opinions relating to improving living and working conditions and industrial relations.

Regarding the legal aspect of Eurofound - over the years, the European regulation establishing the European Foundation for the Improvement of Living and Working Conditions has been amended many times. Amendments to the regulation have been introduced 28 times by several legal acts. The reasons for created changes and replacements were contingent on the current EU policy of accession of individual countries to the Community. The other changes were introduced for financial reasons, with a particular focus on the implementation of EU budgets.

Societal factors also influenced the implementation of changes in the legal basis of the European Foundation for the Improvement of Living and Working Conditions. Changes over the years in the field of labour law and social life have forced the necessity to update the working principles of Eurofound. As a result, the European Union provides the highest level of protection to its citizens. ${ }^{2}$

1 European Foundation for the Improvement of Living and Working Conditions (Eurofound), [online]; (https://europa.eu/european-union/about-eu/agencies/ eurofound_en), (accessed: 11.08.2018).

2 See Regulation (EEC) No 1365/75 of the Council of 26 May 1975 on the creation of a European Foundation for the improvement of living and working conditions, OJ L 139, 30.5.1975, p.1. 
The working area of the Foundation covers: living conditions, working conditions and industrial relationships. ${ }^{3}$ The Foundation is divided into three departments: Administrative Board and the director with deputy director and Committee of Experts. The Administrative Board consists of 30 members, of whom:

- nine members represent the employees' organisations,

- three members represent the Commission,

- nine members represent the Governments of the Member States,

- nine members represent the employers' organisations.

Members are elected by the Council for three-year terms. There is a possibility of extending the term. The Council elects one member for each Member State and for each of the aforementioned categories. After the expiration of their term in office or in the event of their resignation, members remain in office until their appointments are renewed or until they are replaced. The Administrative Council, its chairman and three deputies are elected for one year. The chairman convenes the Administrative Board at least twice a year and at the request of at least one third of its members. All decisions of the Administrative Board are to be adopted by an absolute majority of its members. The Administrative Council operates according to the Procedural Rules approved by the Council after consultation with the Commission. The Administrative Board administers the Eurofound and lays down its guidelines after consultation with the Committee of Experts. On the basis of a draft submitted by the director, the Administrative Board, in agreement with the Commission, adopts the programme of work. The Council has the right to decide whether to accept or reject donations from sources other than the EU. ${ }^{4}$

The director and deputies constitute another significant body. The Commission elects the director and the director's deputies, which are appointed by the Administrative Board from among the candidates' offers. The director and director's deputy are independent and elected for a five-year term with possibility of extension. The director is the head of the Foundation. The director's main tasks include:

- employing and dismissing employees. The director specifies the recruitment requirements,

3 T. Beken, Organised Crime and Vulnerability of Economic Sectors: The European transport and music sector, Maklu Publishers 2005, p. 140.

4 Improvement of living and working conditions in the EU http://www.europedia. moussis.eu/books/Book_2/5/13/05/?all=1 (accessed: 07.12.2016). 
- the direct of the Foundation implements the Decisions of the Administrative Board,

- the director plans the activities of the Administrative Board. The director, or the deputy director, or both, attend the meetings of the aforementioned board.

The director of the Administrative Council is responsible for running the Foundation. Currently, Juan Menéndez-Valdés (Spanish) is the director of Eurofound, and Erika Mezger (German) is his deputy.

The last body to be discussed is the Committee of Experts. The Committee of Experts consists of twelve members appointed by the Council, based on a proposal presented by the Commission, and are selected from among scientific circles and other groups involved in the Foundation's activity. The Committee of Experts has to react upon request or on its own initiative, submit reports covering all working areas of Eurofound to the director and to the Council. The Committee appoints a chairman from among all the members of the Committee of Experts. The Committee operates on the basis of the Procedural Rules. The chairman convenes a meeting of the Committee twice a year or at the request of seven members.

It is worth mentioning that Eurofound has a representative in Brussels, and the Head of the Office is Sylvie Jacquet. This person serves two roles:

- monitoring developments concerning strategic decision-making,

- increasing the visibility and impact of Eurofound research on the politics and social work of the EU.

The personnel of the Foundation consists of members employed by the director and experts from the government administration of the EU countries. All activities of the European Foundation for the Improvement of Living and Working Conditions are funded based on means from the European Union budget. ${ }^{5}$

Eurofound is not a large institution, but its authorities, their rights and obligations are precisely regulated. The institution functions smoothly and without unnecessary delay. From the perspective of the European labour law, the body consisting of experts is the most significant. This body conducts numerous studies concerning the quality and working standard

5 A. Doliwa-Klepacka, Z. M. Doliwa-Klepacki, Struktura organizacyjna (instytucjonalna) Unii Europejskiej [Organisational (institutional) structure of the European Union], Wydawnictwo Temida 2009, pp. 401-403. 
as regards employees. It analyses what should be improved and what needs to be changed. It also determines the standards. Members of the body of experts include only scientists whose objective is to develop a plan for improving the standards of living and work. ${ }^{6}$ Undoubtedly, the source of European labour law includes reports issued by experts who influence policy in the EU.

\section{Activities and objectives of the European Foundation for the Improvement of Living and Working Conditions}

Eurofound operates based on the framework programme for 2017-2020. The new Eurofound programme covers six areas of research:

- working conditions and sustainable work,

- quality of life and public services,

- labour market change,

- industrial relations,

- the digital age: Opportunities and challenges for work and employment,

- monitoring convergence in the European Union.

The new plan is combined with the previous one. The first four pillars refer to the institution's previous research. They cover the main ongoing activities and ensure the continuity of the work and expertise of the European Foundation for the Improvement of Living and Working Conditions. The last two areas of intervention are of a different character. They represent cross-cutting challenges and paradigmatic changes. Although all are important, the amount of work for each strategic intervention area is not symmetrical: "For all areas, Eurofound will examine how living and working conditions can be improved through public policies and legislation, through the intervention of the social partners, and through practices at workplace level."

6 T. Beken, op.cit., p. 140.

7 See Regulation (EEC) No 1365/75 of the Council of 26 May 1975 on the creation of a European Foundation for the improvement of living and working conditions, OJ L 139, 30.5.1975, p. 1. 
Eurofound adapts new programmes to the changing labour market of the EU, including the most important areas in which improvement is essential. ${ }^{8}$

The author of the text would like to focus more on the previous programme for the years 2013-2016, which has a significant impact on the article - The Eurofound programme for the years 2013-2016, adopted on the 29.06.2012 by the Governing Board. As part of the four-year program, the annual programme is implemented. The activities of the Foundation focus on four pillars. Their purpose covers:

- improving working conditions and making work sustainable,

- promoting social cohesion despite social differences and improving living conditions,

- overcoming unemployment by creating new job places and increasing labour market participation, improving the labour market, its functioning, as well as promoting integration,

- developing industrial relationships to ensure equitable and productive solutions in a changing policy context. ${ }^{9}$

The European Foundation for the Improvement of Living and Working Conditions focuses primarily on the pillars mentioned above and provides high-quality knowledge which is relevant for its policy. In order to improve the quality of work of the Foundation, as regards each specific area of research, they are divisible into groups in order to improve the quality of research. The main research groups are:

- youth in Europe - ensuring better prospects for development,

- stability of employment - the development of future employment in Europe,

- social dialogue in Europe - enhancing its role in a changing context,

- the practice of providing mutual benefit - good working conditions for highly productive workplaces,

- mobility and migration - solution to the problem of employment and the consequences of social isolation and migrants,

8 Eurofound, Programming document 2017-2020, 20.12.2016, https:// www.eurofound.europa.eu/publications/work-programme/2016/programming -document-2017-2020.

9 Council Decision No 252/2013/EU of 11 March 2013 establishing a Multiannual Framework for 2013-2017 for the European Union Agency for Fundamental Rights, OJ L 79, 21.3.2013, p. 1-3. 
- services of general interest for Europe - ensuring access, quality and durability,

- employment - the maintenance, development and replacement of jobs in Europe,

- social cohesion - the fight against poverty and social exclusion and social differences,

- trends in the quality of life - impact of the crisis and the European middle class,

- older people - to solve the problems connected to work and health.

Research programmes are conducted within the framework of the individual pillars of the Foundation and its initiatives. Every five years, the Foundation selects a particular group of workers in the EU and conducts studies, then issues opinions. The Foundation established the European Monitoring Centre on Change to monitor the reforms and changes concerning labour law and the social life of EU Member States. It established the European Industrial Relations Observatory and the European Working Conditions Observatory in March of 2016. These two institutions were combined together to create the European Observatory Network. The aforementioned institutions publish reports on their activities and research from time to time. Moreover, the Foundation established the European Network of Cities for Local Integration Policies concerning migration. Its main objective is to support the development of social and economic migrants. The Foundation runs an information centre, where one can obtain information about living and working conditions. In addition to numerous institutions established by the European Foundation for the Improvement of Living and Working Conditions, it runs numerous collections. Several times a year, it issues a magazine titled "Communique", which contains articles about living and working conditions. Once a year, it publishes a few items on selected issues in the field of conditional life and work in the EU. ${ }^{10}$ What is more, from time to time, Eurofound publishes the "European Review of Living" and "Overview of the European Quality of Life". These magazines are of great importance as regards labour law in individual countries. They reveal the problems to be solved by the Member States. Every year, the Foundation's delegation visits selected EU countries. During the visit, the delegation meets with ministers to discuss cooperation and the existing problems in the field of conditional work and life. In addition, naturally, the European Foundation for the Improvement of Living 
and Working Conditions cooperates closely with other organisations, such as the European Agency for Safety and Health at Work. ${ }^{11}$

Each of these groups deals with relevant and existing problem areas in the field of labour law. Unemployment of young people remains a valid issue, not only in Eastern Europe, but also in countries such as Spain and Portugal. Thanks to the research concerning these problems, the European Union can take appropriate steps and force EU Member States to undertake appropriate measures aimed at resolving the problems in this areas.

\section{Practical activities of the Foundation. Social dimension of intra-EU mobility and its impact on public services}

The most significant values of the EU include the freedom of movement of its citizens within the framework of the community. However, the majority of countries discuss and control the impact on their mobility within State public services. The debate focused on the problem of "welfare magnet hypothesis". Citizens of Eastern Europe often immigrate to the countries of Western Europe due to the social benefits and social assistance services. In reference to the crisis in Europe, this issue is often raised by the media and the EU. That is why this issue is interesting and worth describing. Eurofound was actively involved in research on the problem and published a report concerning the issue. The main objective was to determine whether there is evidence to support the hypothesis of attracting social conditions. These observations included research on: the level of use of services and social benefits for citizens of ten EU countries (Eastern Europe and Central Europe) in nine host countries (Austria, Denmark, Germany, Ireland, Italy, Netherlands, Spain, Sweden and the United Kingdom). The Foundation compared the results with family members and citizens who still live in Eastern and Central European countries. Moreover, the project aims at identifying obstacles to their integration in the host countries and identify initiatives to support this integration. Ministers of foreign affairs of the following countries: Austria, Germany, the Netherlands and United Kingdom, directed a letter to the President of the European

11 Fourth European Working Conditions Survey, Denmark 2007, http://www. newunionism.net/library/working\%20life/Eurofound\%20\%20European\% 20 Working\%20Conditions\%20Survey\%20-\%202007, (accessed: 13.11.2016). 
Council, which claimed that mobile citizens from EU-10 countries placed additional stress on public services in their countries, in particular education, health and housing, and that they benefit from social assistance, often without having these rights. In 2013, the European Commission presented a report which proposed five solutions concerning this issue, in particular, the need to support local authorities and States within the EU, and reminded the Member States that they have a shared responsibility for "the implementation of the provisions on freedom of movement for the benefit of citizens, economic growth and employments". Earlier studies show that the dependence of migrants on social assistance is greatly reduced due to faster integration in the host country. However, there is a lot of evidence showing that the citizens of the EU-10 have problems with integration. According to the programming document of the European Commission from 2012, there are several ways of integrating newcomers concerned to EU-10 12 citizens in the countries to which they arrive. ${ }^{13}$

The study identified the key issues and the manner of solving them. The main key findings include:

- the level of migrant citizens from the EU-10 using benefits and social welfare services is significantly lower in comparison to the native population, in particular as regards social housing and pensions. There are certain benefits, in particular the provision of employment and unemployment for which the citizens of the EU-10 apply more often than native nationals. On the other hand, there are many indications suggesting that the arrival of migrants from the EU-10 can have a fiscally positive impact on the economic situation in host countries.

- immigrants migrate mainly due to work, making use of the benefits related to employment. Education benefits relate primarily to their children.

- their weaker position on the labour market and lower wages have significant implications as regards the use of their benefits and their demand for social services.

12 The 10 countries that joined the EU in 2004: Cyprus, the Czech Republic, Estonia, Hungary, Latvia, Lithuania, Malta, Poland, Slovakia and Slovenia. They joined the European Union on 1.05.2004.

13 K. Foti, Social dimension of intra-EU mobility: Impact on public services, Publications Office of the European Union 2015. 
- the level of mobile EU-10 citizens using social housing is dramatically lower compared to the native population.

The main challenges concerning the fight against the aforementioned problem is that:

(...) certain services do not always meet the needs of mobile EU-10 citizens. For example, employment services do not provide help with recognition of diplomas, or access to benefits in the host country can be problematic even for eligible EU-10 citizens, partly because of difficulties with navigating the often complicated social welfare systems, and partly because they often lack information and language skills. ${ }^{14}$

The results of the study were used to prepare proposals for a solution to the problem:

- increased support for employment for migrant EU citizens due to their unfavourable status on the labour market and difficulties concerning integration in society;

- state must observe and record which migrant nationalities benefit most from social benefits;

- migrant organisations in particular require more financial support, so that, in close cooperation with public authorities, they can satisfy the increased needs and widen the degree of integration;

- stronger financial support as regards learning the language of the host country.

The study provided manners to be implemented in order to reach an agreement and to eradicate difficult situations. Based on the text above, the Foundation participates in research on current issues and presents concrete solutions to help host countries. Moreover, these studies show that the citizens of EU-10 can have a positive economic impact on the host countries and that, unfortunately, they are treated in a less favourable manner than the nationals of the host country. These studies show that scientific activities of Eurofound undoubtedly have a large impact on the policy of EU labour law. 


\section{Summary}

Based on this text, one can state that the Foundation for the Improvement of Living and Working Conditions is a strictly regulated organisation understanding its purpose and seeking improvement as regards the quality of life and work. This can be noticed not only while analysing the work of its bodies, but also in other areas covered by the operations of governmental organisations.

The website of the Foundation, which is divided into seven areas, operates very well. These areas include: about the Foundation, publications, topics, research, observatories, news and events. Each of these areas are of a scientific nature. The research areas are divided according to the fields covered by the work of the Foundation. This tab includes useful information from various EU countries as regards work and life. Any changes to the legal and political importance are presented in the event section. It is worth noting the publication section as well. It includes interesting articles useful not only for lawyers or a scientist, but also for ordinary citizen. These articles and reports enable students to acquiring knowledge as regards the problem areas of labour law and living conditions. They are also written in an accessible language. Moreover, the Foundation is involved in court cases by presenting their opinions concerning the proceedings. The webpage of the Foundation presents important judgments which proved to be crucial.

The Foundation for the Improvement of Living and Working Conditions does not limit itself to practical activity only. The Foundation operates extensively within the scientific field. It organises and participates in numerous scientific seminars and takes part in international conferences. Eurofound supports technologies, etc., and plays an important role in the politics of the EU.

If in Europe a particular sort of practice in the workplace becomes popular, such as the practice of a win-win solution, the Foundation begins research devoted to that practice, and will publish its findings. ${ }^{15}$

This paper clearly shows that the Foundation for the Improvement of Living and Working Conditions is an irreplaceable organisation. The activities of this organisation have a wide range and cover many areas.

15 S.R. Nilsen, Women and Low-Skilled Workers: Other Countries' Policies and Practices that May Help these Workers Enter and Remain in the Labor Force, DIANE Publishing 2007, p. 30. 
Cooperation with numerous organisations only reinforces the importance and position of the Foundation. Reports issued by the Foundation for the Improvement of Living and Working Conditions are significant. The Foundation plays a key role in the development and improvement of labour law and living conditions, successfully promoting equality of employment, better working conditions and supporting social integration. ${ }^{16}$

Eurofound was established by the European Union institution to provide knowledge to assist in the development of better social, employment and work-related policies, and undoubtedly, one can state it fulfils the role it was created for.

\section{Bibliography}

1. Beken T., Organised Crime and Vulnerability of Economic Sectors: The European transport and music sector, Maklu Publishers, Antwerp-Apeldoorn, 2005

2. Doliwa-Klepacka A., Doliwa-Klepacki Z.M., Struktura organizacyjna (instytucjonalna) Unii Europejskiej, Wydawnictwo Temida 2009

3. Foti K., Social dimension of intra-EU mobility: Impact on public services, Publications Office of the European Union 2015

4. Nilsen S.R., Women and Low-Skilled Workers: Other Countries' Policies and Practices That May Help These Workers Enter and Remain in the Labor Force, DIANE Publishing 2007

16 Ibidem. 